\title{
ANALYSIS OF SYNTHETIC ADULTERANTS, MEAN WEIGHT AND LABELING IN TRADITIONAL PHYTOTHERAPIC PRODUCTS
}

Bruno Vincenzo Fiod Riccio, Pamella Cristina Oliveira Françóia, Paula Olsen Sorgatto, Airton Vicente Pereira, Stella Bortoli

Universidade Estadual de Ponta Grossa - UEPG, PR. e-mail: stellabortoli@gmail.com

\begin{abstract}
Traditional phytotherapic products (TPP) use is nowadays common in society. As they are known to be natural products, there is an assumption that the effects are exclusively beneficial and the potential harmful effects are disregarded. As well as adulterations with synthetic drugs capable of masking adverse effects or acting synergistically with biologically active compounds, potentiating their effects, considered by law as fraud. The aim of the present study was to evaluate common TPP and its compliance with the current law regarding labeling, average weight and research on synthetic adulterants using comparative thin layer chromatography. Twenty PTFs were evaluated, of which all failed the labeling assessment, one contained average weight consistent with legislation and there was no evidence of adulteration by increment of synthetic drugs in any of them. Evaluating the quality of a product ensuring its compliance with the legislation is crucial for the reliability of consumers and the credibility of producers.
\end{abstract}

Keywords: traditional phytotherapic products, adulteration, labeling, average weight, comparative thin layer chromatography

\section{ANÁLISE DE ADULTERANTES SINTÉTICOS, PESO MÉDIO E DE ROTULAGEM EM PRODUTOS TRADICIONAIS FITOTERÁPICOS}

\section{RESUMO}

O uso de produtos tradicionais fitoterápicos (PTF) é um costume comum na sociedade atual. Por serem produtos ditos naturais, há a suposição dos efeitos serem exclusivamente benéficos e os potenciais efeitos nocivos desconsiderados. Assim como as adulterações com fármacos sintéticos capazes de mascarar efeitos adversos ou atuar sinergicamente com compostos biologicamente ativos potencializando seus efeitos, considerado pela lei como fraude. O objetivo do presente estudo foi avaliar PTF comuns e suas conformidades com a lei atual quanto rotulagem, peso médio e pesquisa de adulterantes sintéticos pelo uso de cromatografia em camada delgada comparativa. Foram avaliados 20 PTF, dos quais todos foram reprovados na avaliação da rotulagem, apenas uma continha peso médio condizente com legislação e em nenhuma houve a comprovação de adulteração por incremento de fármacos sintéticos. Avaliar a qualidade de um produto garantindo sua conformidade com a legislação é determinante para a confiabilidade dos consumidores e credibilidade dos produtores.

Palavras-chave: produto tradicional fitoterápico, adulteração, rotulagem, peso médio, cromatografia em camada delgada comparativa

\section{INTRODUCTION}

The currently aesthetic standards imposed by society lead people to believe that they need to achieve the lean body. There are many ways to achieve it, but due the sedentary lifestyle, fast and miraculous solutions are often 
searched $^{1}$. One of the most widespread alternatives is the use of traditional phytotherapic products (TPP) for weight loss². Anti-obesity drugs such as anorexigenics are employed in appetite reduction, which consequently leads to the weight loss. Owing to the common belief that natural products are pure benefic or at least harmless, people thrust they can be used with no ponder ${ }^{3}$.

Due this misconception, costumers have easy access to these products and no surveillance to obtain them, which makes producers to overuse the "natural" appeal in their labels and propagandas 4,5 . However, phytotherapics act in the organism the same way as synthetic drugs and may cause adverse effects to their users as well ${ }^{5}$. They can also interact with other phytotherapics or synthetic drugs, which may boost or decrease their effects, what may bring risks to the health of their consumers ${ }^{6}$.

Some studies suggest that many of these substances act over the appetite control center in hypothalamus through chemical modulators, causing the sensation of satiety ${ }^{7}$. Thus, these drugs can stimulate the central nervous system and are classified in two major groups: (i) stimulants of central catecholamine pathways, increasing the synaptic concentration of catecholamines by their reuptake inhibition and enhancement of their release and; (ii) serotoninergic pathway stimulants, by interacting with amine transporter systems, and then decreasing synaptic reuptake of serotonin, which increases its neurotransmission ${ }^{8}$. However, there are many adverse effects when using these drugs, including increase of blood pressure and heart rate, xerostomia, constipation, insomnia, and drug interactions ${ }^{9}$.

There are two most common groups of frauds in TPP: the economic adulteration, that occurs due the use of less expensive ingredients than the ones declared on the label; and the pharmaceutical adulteration, based in the addition of an active drug in order to enhance the pharmacological effects of the product ${ }^{10}$.

The World Health Organization (WHO) states that plant-based medicines combined with chemically defined active compounds are not allowed to be in herbal medicines classification and consequently as TPP as well, indicating that these products are prohibited to have synthetic drugs in their compositions ${ }^{10}$. Amongst the most common adulterating drugs found in phytotherapics, there are anabolic steroids, anti- inflammatories, sexual performance enhancer drugs, antihypertensive, and sibutramine ${ }^{11}$.

The addition of caffeine to TPP is one of the most common adulterations in these products because of the synergic effect of the associations, which improves the stimulant effect and increases the dopaminergic release ${ }^{12}$. Although it is not as noxious as it seems, high doses of caffeine or the increase of its potency can leads to malfunctions in gastrointestinal system, heart palpitations and other health problems ${ }^{12}$.

Though any undeclared addition of synthetic drugs have harmful potential, some drugs are worse than others. To decrease the probability of causing deleterious effects, some producers also take advantage of the interactions of appetite suppressants with synthetic drugs, such as antidepressants and benzodiazepines $(B Z D)^{13}$.

Diazepam is a BZD with anxiolytic effect and has employment in the treatment of anxiety and panic disorders. It also is used in clinical cases of intoxications caused by slimming products overdoses, which explains the need of its research in TPP ${ }^{13,14}$. Chlordiazepoxide, in instance, is another BZD with hypnotic properties used for anxiety and alcohol withdrawal being able to mask the adverse effects of adulterer TPP, but there are evidences that overdoses can cause potential lethal comorbidities, including respiratory failure, depression, and drivingrelated issues ${ }^{15}$.

Fluoxetine is a selective serotonin reuptake inhibitor of the class of the antidepressants that can be used as off-label to cause weight loss boosting the effects of this kind of TPP and preventing some of their adverse effects such as anxiety. Nevertheless, it has the possibility to induce mental problems, including suicidal thinking and seizures ${ }^{16}$. Sibutramine, is a drug used for treatment of metabolic syndromes and for common visceral obesity being an inhibitor of norepinephrine and 5hydroxytriptamine $(5-\mathrm{HT})$ being able to be employed as a weight loss agent. The Food \& Drugs Administration (FDA) reports that it brings more risks than benefits when it comes to cardiovascular adverse effects, increasing the chance of trigger health problems, including nonfatal heart attacks and strokes, and cardiovascular death ${ }^{17}$.

In an attempt to avoid problems with the law, some TPP are commercialized under the 
classification of dietary supplements being legally considered as foods ${ }^{18}$. It is a convenient strategy since foods are regulated, controlled, and have their inspections according to the Federal Law $n$. $9,782 / 1999^{19}$ and to the Resolution n. $18 / 1999^{20}$, which demands researches about their nutritional compositions and mentioning nothing about researches that elucidate the presence of synthetic drugs ${ }^{21}$.

According to the article 18 of the Consumer Protection Code, the producer responses for disparities in quality and quantity in which turn their products improper for consumption or that reduces their value, including unconformities of information described in the labels, what makes necessary the evaluation of their information to prevent frauds ${ }^{22}$.

The weight uniformity is another useful parameter to compare the conformity of the drug content to what is expressed in the label and to suffice as comparative to the results of chemical analysis. The Bazilian Pharmacopeia $5^{\text {th }}$ edition gives subsidy to this analysis and the parameters that have to be in accord to the current legislation ${ }^{23}$.

One of the most simple, inexpensive and useful analytical methods is the Comparative Thin Layer Chromatography (CTLC). It consists in separating a mixture of non-volatile compounds based in difference of affinities between the compounds with the surface of the adsorptive phase $^{24}$. A mobile phase migrates over the stationary phase and drags the samples from the starting points, being the less adsorbed compounds easily dragged than the most adsorbed. The process stops when the mobile phase reaches the finish line, previously demarcated. Thereby is possible to calculate the retention factor (Rf) to identify the substances composing the formulations under analysis comparing it to reference substances or analytical standards ${ }^{25}$.

The purpose of the present study is to analyze samples of TPP by their labels conformity, weight uniformity, and CTLC in order to evaluate possible adulterations by the addition of synthetic products and conformities on their labels. The noncompliance of the instructions and obligations arranged by law can cause serious health problems and to prove that practical methods such as CTLC can be useful to discover adulterations by the most common synthetic drugs in TPP.

\section{METHODOLOGY}

For this study, 20 samples of TPP were randomly acquired in different establishments in the city of Ponta Grossa, Brazil. Among the 20 samples, one was in non-coated tablet form and the other 19 were in the form of hard capsules. Their compositions are described in Table 1.

Labelling analysis and compliance were analysed according to the state $R D C$ n. 26/2014 ${ }^{26}$; Instrução Normativa n. 4/2014 ${ }^{27}$; and the Consumer Protection Code ${ }^{22}$. For the mean weight analysis, the methodology described in Brazilian Pharmacopeia $5^{\text {th }}$ edition $^{23}$. The following parameters were analyzed: commercial name, botanical nomenclature, rout of administration, data of the manufacturing company (CNPJ), contact of customer service, data of the technical manager, notification from ANVISA (Brazilian Health Regulatory Agency Agência Nacional de Vigilância Sanitária), date of manufacture or validity, batch number, contraindications, the sayings present in items $\mathrm{VII}, \mathrm{IX}, \mathrm{X}$ and $\mathrm{XI}$ of the Article 57 of the $R D C \mathrm{n}$. $26 / 2014$, preservation care, the phrase "TRADITIONAL PHYTOTERAPIC PRODUCT", warning phrases described in article 58 of $R D C \mathrm{n}$. $26 / 2014$, and other unconformities at the labels. According to this $R D C$, TPP need to own primary and secondary packaging, information leaflet for the patient informing pertinent data, such as its posology, the correct use, and adverse effects. However, if all the information provided in this law presents themselves as legible directions, the product is able to have only a primary packaging and the information leaflet.

Weight uniformity: determined by individual weigh of 20 unities of each sample, as recommended by Pharmacopeia ${ }^{23}$.

Adulteration research: Samples were analyzed using CTLC method. 
Table 1. Composition of the acquired samples, according to their labels.

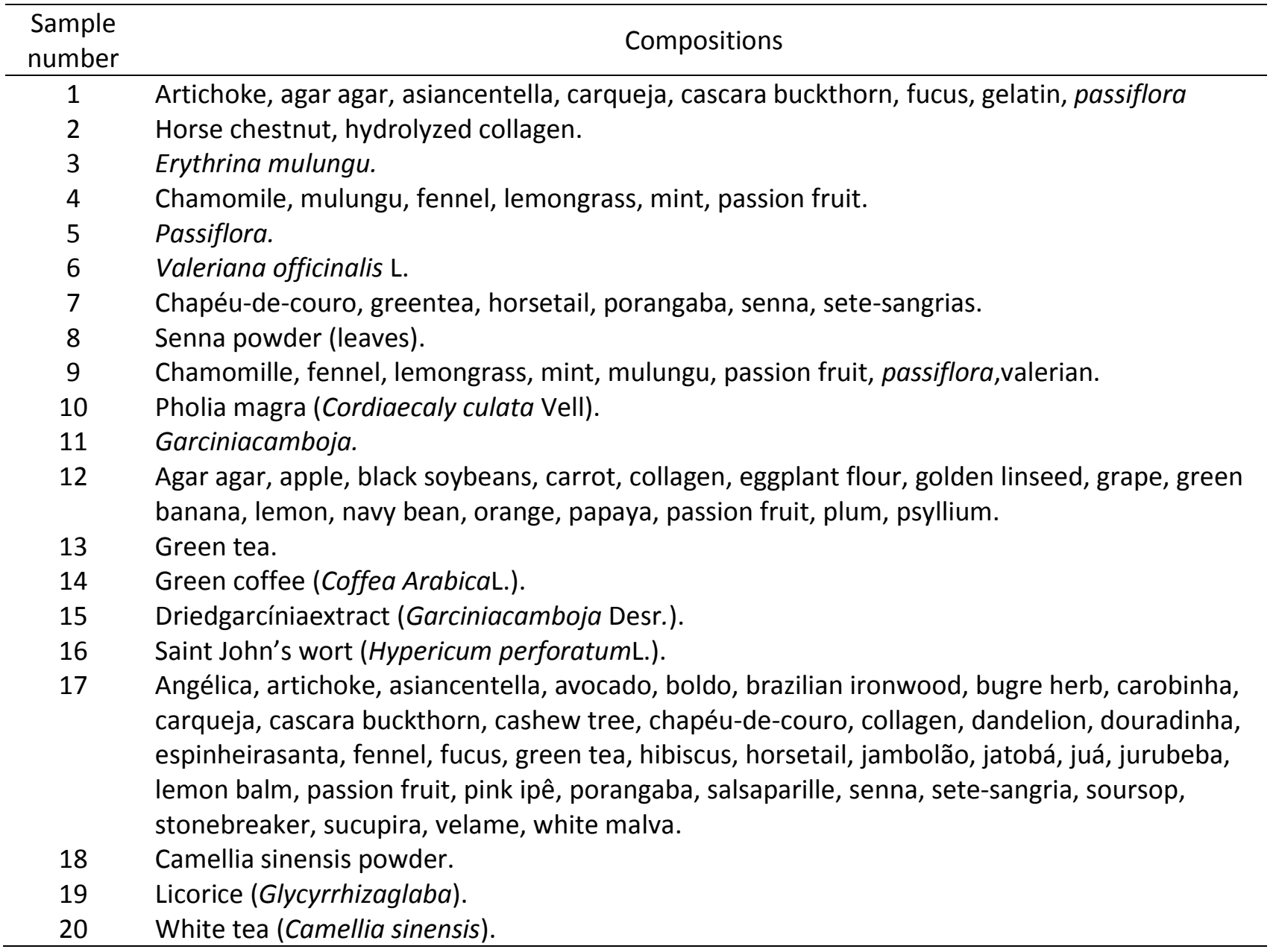

Standards: analytical standards were obtained in manipulation pharmacies as certified materials in accordance with the Methodological Guidelines: Elaboration of Clinical Guidelines ${ }^{28}$ and $R D C$ n. $9 / 2015^{29}$ accompanied by certificates of quality control analysis. Four of them were selected: chlordiazepoxide, diazepam, fluoxetine, and sibutramine. The selected caffeine standard for the analysis was the Merk ${ }^{\circ}$ Caffeine analytical grade. Solution at the concentration of $1 \mathrm{mg} / \mathrm{mL}$ was prepared for each standard, methanol was used as diluent.

Samples preparation: the tablets were smash and the capsules opened to obtain their powders. Then, $1 \mathrm{~g}$ of the obtained powder were weighed, transferred to an assay tube being added $5 \mathrm{~mL}$ of methanol, and submitted to vortex agitation for three minutes. Samples solutions were filtered, and then the filtrate was kept at room temperature to completely evaporate the solvent in fume hood.

Stationary phase preparation: the chromatographic plates were made in glass support with $20 \times 20 \mathrm{~cm}$ and thickness of 0.25 $\mathrm{mm}$ with silica gel G60. A suspension were prepared with $30 \mathrm{~g}$ of silica and $60 \mathrm{~mL}$ of distillated water and evenly distributed over the glass plates previously cleaned by ethyl alcohol $92 \%$. A specific support was used to obtain a silica layer with $500 \mu \mathrm{m}$ of thickness. The plates were dried at room temperature and activated prior their use in incubation at $105{ }^{\circ} \mathrm{C}$ for 1 hour. As alternative and confirmation purposes TLC plates silica gel 60 (without fluorescent indicator) precoated plates $20 \times 20 \mathrm{~cm}$ layer thickness $0,25 \mathrm{~mm}$ form Merck (art.5721) were used.

Solvent system preparation: A. Chloroform: acetone (90:10, v/v; used for benzodiazepines, caffeine, and sibutramine analysis); B. Ethyl acetate: methanol: ammonium hydroxide (85: 10: 5, v/v/v; used for fluoxetine analysis).

Preparation of the detection reagents: for the chromatographic development of the plates were used the previously made chemical reagents Dragendorff and platinum iodide. 
Before the application of the chemical developers, the plates were observed in UV chamber of $8 \mathrm{~W}$ ( $\lambda$ max: $253 \mathrm{~nm}$ ). Dragendorff reagent: $4 \mathrm{~g}$ of bismuth subnitrate was dissolved in $100 \mathrm{~mL}$ of distillated water. Thereafter, $20 \mathrm{~mL}$ of nitric acid analytical grade and $13.5 \mathrm{~g}$ of potassium iodide were added. Platinum iodide: A stock solution was made by dissolving $0.2 \mathrm{~g}$ of hexacholoroplatinic acid in $20 \mathrm{~mL}$ of potassium iodide $10 \%(\mathrm{~m} / \mathrm{v})$. The developer solution was prepared by diluting the stock solution with a solution of hydrochloric acid $4 \%(\mathrm{v} / \mathrm{v})$ at the proportion of 1:5.

Chromatographic developing: firstly, the chromatographic chambers were saturated with both solvent systems $A$ and B. After the evaporation of the solvents, the samples were resuspended with $200 \mu \mathrm{L}$ of methyl alcohol, getting a final concentration of $5 \mathrm{mg} / \mathrm{mL}$, then, $100 \mu \mathrm{L}$ of each sample was applied in triplicate in the activated plate, at a distance of $2 \mathrm{~cm}$ of the inferior border. The running distance of the solvents was standardized in $16 \mathrm{~cm}$. At the end of the running, the plates were submitted to revelation in UV chamber. Posteriorly, the developer platinum iodine was applied and then the Dragendorff reagent. The migration distance of the stains revealed was measured for posterior calculations of the Retention factor (Rf).

Limit of Detection (LOD): The LOD of the chromatographic method was accomplished from the preparation of standard solutions with the following concentrations: $1.0 \mathrm{mg} / \mathrm{mL}, 0.5 \mathrm{mg} / \mathrm{mL}$, $0.25 \mathrm{mg} / \mathrm{mL}$, and $0.1 \mathrm{mg} / \mathrm{mL}$. These solutions were submitted to the same chromatographic procedure as the samples.

\section{RESULTS}

There were analyzed 20 TPPs samples as described in Table 1.

The labels analysis were conducted according to $R D C$ n. $26 / 2014^{26}$. To be in accordance with law, a sample needs to show all the parameters specified in technical regulation, or apply to its exceptions. The parameters analyzed and results are described in the Table 2.

These information are necessary to assure that the industry provides all the required and correct information and that the patients know what they are purchasing and consuming. Mean weight: The mean weight determinations were realized according to the Pharmacopeia ${ }^{23}$. All the labels of the samples in the form of hard capsules brought the mass indication greater than $300 \mathrm{mg}$, thus their allow variations are up to $\pm 7.5 \%$, while non-coated tablets indicated mass of $800 \mathrm{mg}$, being able to vary up to $\pm 5 \%$ and in both cases, none can be above or under twice the percentages indicated. It also brings the information that no more than 2 unities in 20 unities of each of the capsules and the tablet samples can be over their specified limits.

Table 2. Results for the label analysis.

\begin{tabular}{lc}
\hline Nonconformities (do not present) & Quantity of samples \\
\hline Commercial name & 16 \\
Botanical nomenclature & 9 \\
Route of administration & 20 \\
Data of the manufacturing company & 18 \\
Company identification CNPJ" & 6 \\
Contact of customer service & 19 \\
Data of the technical manager & 20 \\
MS register number nor notification from ANVISA & 20 \\
Date of manufacture or validity & 9 \\
Batch number & 5 \\
Contraindications & 20 \\
The phrases on items VII, IX X, and XI of Art. 57 of the RDC n. 26/2014 & 20 \\
Preservation care & 9 \\
The phrase “TRADITIONAL PHYTOTERAPIC PRODUCT" & 20 \\
The warning phrases described in the Art. 58 of RDC n. 26/2014 & 20 \\
Unconformities in terms or phrases declared in the label & 3
\end{tabular}

"CNPJ - Cadastro Nacional da Pessoa Jurídica. 
The results shown that only one of the samples was within the established limits (sample 2 ), being the only one in accordance with the legislation. One of them did not declare the weight of its capsules in the label (sample 7). Therefore, it was not possible to determine if it complied the current legislation. The samples 3 , $6,8,9$, and 12 were disapproved with $19,18,14$, 5 , and 16 unities with discrepant values, respectively. All the other samples reproved due the fact of all of their 20 unities were in disaccord to the recommended by Pharmacopeia ${ }^{23}$. With these results, it is possible to affirm that only $5.25 \%$ of the samples were approved for this parameter.

Analysis of samples adulteration:

Prior to choose of the standards used in this study, a pre-analytical research was made with non-analytical standards present in the laboratory of toxicology of Ponta Grossa State University to test the methodology, being they: alprazolam, amfepramone, bromazepam, clonazepam, diazepam, fenpropopex, fluoxetine, nitrazepam, and piroxicam. In addition, prior to analysis, the standards were tested by CTLC method to define their detection limits and the retention factors (Rf).

The limit of detection was obtained through the methodology previously described. It was possible to observe that the detection limits was $0.25 \mathrm{mg} / \mathrm{mL}$ for caffeine, clordiazepoxide, diazepam, sibutramine, and fluoxetine. Results are showed in Table 3.

Table 3. Results for the standards analysis by CTLC.

\begin{tabular}{lcccccc}
\hline Standard & $\begin{array}{c}\text { Mobile } \\
\text { phase* }\end{array}$ & $\begin{array}{c}\text { UV }(\lambda \max \\
253 \mathrm{~nm})\end{array}$ & $\begin{array}{c}\text { Platinum } \\
\text { iodide }\end{array}$ & $\begin{array}{c}\text { Dragendorff } \\
\text { reagent }\end{array}$ & $\begin{array}{c}\text { Spot distance } \\
(\mathrm{cm})\end{array}$ & $\mathrm{Rf}^{* *}$ \\
\hline Caffeine & $\mathrm{A}$ & Yes & - & Orange & 4.7 & 0.29 \\
Chlordiazepoxide & $\mathrm{A}$ & Yes & Purple & Brown & 3.3 & 0.21 \\
Diazepam & $\mathrm{A}$ & Yes & Purple & Brown & 10.9 & 0.68 \\
Fluoxetine & $\mathrm{B}$ & No & Purple & Orange & 4.3 & 0.27 \\
Sibutramine & $\mathrm{A}$ & No & Blue & - & 10.1 & 0.63 \\
\hline
\end{tabular}

* Mobile phase: $A$ - chloroform:acetone (90:10); B - ethyl acetate:methanol:ammonium hydroxide (85:10:5)

** $R f=$ Spot distance $(S D) /$ Mobile phase distance $(M D=16)$.

Twenty samples were analyzed in triplicate for the presence of these synthetic compounds. In $50 \%$ of them, no spot was observed after the detection reagent was sprayed, what indicates the absence of the investigated compounds in the samples. The results from the other 10 samples, on the other hand, showed that 7 of them had chromatographic profiles similar to at least one of the standards previously tested at mobile phase A (chloroform:acetone (90:10)) and due to this characteristic, they were reanalyzed in triplicate within the respective standard to confirm the proximity of the Rf values. The results are presented in the Table 4.

Table 4. Chromatographic profiles for the samples.

\begin{tabular}{cccccc}
\hline $\begin{array}{c}\text { Sample } \\
\text { number }\end{array}$ & $\begin{array}{c}\text { UV } \\
(253 \mathrm{~nm})\end{array}$ & $\begin{array}{c}\text { Platinum } \\
\text { iodide }\end{array}$ & Dragendorff & SD $(\mathrm{cm})$ & $\mathrm{Rf}$ \\
\hline 3 & Yes & Purple & Maroon & 4.1 & 0.25 \\
7 & Yes & Lilac & Brown & 4.2 & 0.26 \\
8 & Yes & Lilac & Orange & 6.1 & 0.38 \\
10 & Yes & Lilac & Orange & 7.8 & 0.49 \\
13 & Yes & - & Orange & 4.2 & 0.26 \\
18 & Yes & - & Orange & 5.0 & 0.31 \\
20 & Yes & - & Orange & 6.5 & 0.41 \\
\hline
\end{tabular}


After the newly chromatographic development, only one sample (13) kept a profile similar to its respective standard, indicating possible presence of caffeine in its content.

Concomitant to the new chromatographic development of the samples listed in the table 1 , it was realized a bibliographic research about their phytochemical compositions in order to elucidate if the TPP present in their composition any compound that react with the chromatographic developers, forming possible false-positive results.

\section{DISCUSSION}

According to the item $X X$ of the article 57 of $R D C \mathrm{n} .26 / 2014^{26}$, the pharmacist responsible for the product needs to have their respective registration on a class council, known as Conselho Regional de Farmácia; besides the decree $\mathrm{n}$. $85,878 / 1981^{30}$ establishes that this is one of the privative professional activities of pharmacists. Among the 20 analyzed samples, in 16 there was no information on the label about their responsible pharmacist, and in 4 samples, the responsible were nutritionists, thus were not in accord with the legislation as well.

The use of terms or phrases alluding the ability to cure grave or chronic diseases, such as obesity, anxiety, cardiac disease, diabetes, and others, is prohibited according to the Instrução Normativa n. 4/2014 ${ }^{27}$. Through the label analysis, 3 samples present this kind of propaganda, so they are in disaccord to legislation. The use of these terms are inadequate and potentially dangerous, due there may be a risk that the consumer will abandon treatment with previously prescribed drugs and replace with natural products, which supposedly have the same therapeutic effects and fewer side effects and thereby aggravate their health conditions.

None of the samples had information leaflet and with that are in disaccord to the regulation. These leaflets are important documents because they bring proper orientations about the correct utilization of the product. As described in article 57 of the $R D C \mathrm{n}$. $26 / 2014^{26}$, it is necessary some warnings about age groups as children, pregnant woman and elderly people (item VIII), time of use (item IX), how to proceed if the symptoms persist (item XI) and others. The samples also should have warnings about being kept out of the reach of children, information about posology and adverse effects on their leaflets, among others.

Some of the analyzed TPP also had no information of their producers, what makes the contact difficult for the consumer in cases of doubts or complaining. The same applies to surveillance inspect in cases of serious problems what makes the products doubtful or, depending on the case, clandestine.

The weight uniformity test ensures that each weight unit, tablets or capsules, contain the desired amount of substance with little variation. By evaluating the weights, is possible to observe that most of the samples (94.75\%; 19 samples) presented themselves with mean weights under the declared in their labels, what causes the consumer to use low quantity of the product than the declared. This kind of failure is an infringement to the Federal Law n. 8,078/1990 (Consumer Protection Code - Código de Defesa do Consumidor $)^{22}$. The real amount of product must match to that declared in the label, being responsibility of the producer assure the conformity of the product.

Presumable interferences were investigated and it is well known that the Dragendorff is an alkaloid specific visualization reagent ${ }^{31}$ that reacts with nitrogen compounds forming brown stains in the plates; while the visualization reagent potassium iodide reacts with anthracenic compounds and starchs forming lilac coloration and golden-brown when reacting to alkaloids ${ }^{13}$.

The sample 3 is composed by Erythrina mulungu. Some phytochemical studies of this plant shown the presence of reductive sugars, phenols, tannins, proteins, amino acids, flavonoids, alkaloids, depsides, derivatives of coumarins, steroids, and triterpenoids. Thereby, it shows compounds able to react to both the developers used in this study, discarding the possibility of adulteration ${ }^{32}, 33$.

The sample number 8 has senna in its composition, a powerful laxative due the presence of anthracene derivatives (anthraquinones) and senosides A and B. They have reactive structures to the chromatographic developers, discarding the possibility of adulteration of the sample ${ }^{34}$.

The green tea (samples 13 and 7) and the white tea (samples 18 and 20) are products of the same plant (Camellia sinensis). While the green tea is a product of the non-fermented leaves, the 
white tea is produced from the flower. This plant has proteins, ascorbic acid, vitamins $A$ and $E$, tannins, caffeine, catechins and other polyphenols ${ }^{35,36}$. The presence of caffeine (an alkaloid) was confirmed in the plant, therefore it is positive to the Dragendorff developer ${ }^{31}$. Both products also have antracenic compounds in their compositions, therefore developing spot stains to platinum iodide reagent as well ${ }^{32}$, discarding possible frauds in these samples.

The sample number 10 contains Pholiamagra (Cordia eucalycylata) in its description. It may have anorectic effect indication, and its main composition is caffeine, potassium, allantoin, allantoic acids ${ }^{37}$. Thus, these compounds can react to the reagents and cause false-positive results as well.

Many studies researched the presence of adulterants by CTLC. Yano at al analyzed 22 samples by CTLC and found the presence of anorectic (anfepramone and femproporex) and the benzodiazepine diazepam in their composition, which was not declared in the labels $^{13}$. Verly and Dominato also used comparative thin layer chromatography to research the presence of benzodiazepines in popular and low-cost herbal medicines. In this work, 5 samples were analyzed and one was positive for diazepam and flurazepam ${ }^{38}$.

The need for a standardization for the use of comparative thin layer chromatography is justified by the fact that this technique is simple and effective in detecting adulterants in herbal preparations. Besides, the importance of discovering these frauds, since many people use these products in indiscriminate way can provide effectiveness and safety to TPPs use ${ }^{39}$.

Adulterations in natural products are still a common public health problem. Even with the existence of national surveillance organs, in Brazil there are many clandestine producers and gaps in the law that facilitate the addition of synthetic compounds in them. Besides, it is necessary the conscience that plants and food products can entail serious health problems. In addition, they need more attention about the most common frauds that they are subject to and plan more effective methods for adulterants research.

As for the analysis of labels, the words print on the label are an important way of communication between producers and consumers. It is very important for the producer to comply with the legislation to guarantee the use with quality, effectiveness and safety of the products. The mean weights also provides supplementary information about quality of the product and guide the consumer to ensure a proper dose. If the eral mean weight differ to the specified in their labels, the consumer can purchase something less or more than they need and problems with doses, which may not achieve effectiveness or cause adverse effects and even toxicity in cases of excess.

The method used in this study, Comparative Thin Layer Chromatography, shown itself suitable to its purpose, since it revealed the presence of compounds naturally present in the samples analyzed. Besides this is a rapid, practical, and affordable method useful for various substances.

The samples of the traditional phytotherapic products did not presented any adulteration related to the presence of synthetic substances analyzed: caffeine, clordiazepoxide, diazepam, fluoxetine, and sibutramine. However, the research for synthetic adulterants in TPP demonstrates the importance of these studies and the need for a better surveillance, since there are many potential harmful drugs that can be use as adulterants and the unfamiliarity of the consumers with these substances entail in a perilous exposition due the possible adverse effects they can be exposed. The unaware ingestion of these substances can be injurious also because of the drug interactions, being able to cause health problems or aggravate them and, specially, this is considered a sanitary risk and a collective health problem.

\section{CONFLICT OF INTEREST STATEMENT}

The authors declare that there is no potential conflict of interest that could interfere with the impartiality of this scientific work.

\section{REFERENCES}

1. Silva AFDS, Neves LDS, Japur CC, Penaforte TR, Penaforte FR. Image-discursive construction of body beauty in social media: effects on followers' body and eating perceptions Construção. DEMETRA Aliment Nutr Saúde [Internet]. 2018; DOI: http://dx.doi.org/10.12957/demetra.2018.33305

2. Bahmani M, Eftekhari Z, Saki K, FazeliMoghadam E, Jelodari M, Rafieian-Kopaei M. Obesity Phytotherapy: Review of Native Herbs Used in Traditional Medicine for Obesity. J Evidence-Based Complement Altern Med 
[Internet].

2015;

DOI: http://dx.doi.org/10.1177/2156587215599105

3. Ekor M. The growing use of herbal medicines: Issues relating to adverse reactions and challenges in monitoring safety [Internet]. Frontiers in Neurology. 2014. DOI: http://dx.doi.org/10.3389/fphar.2013.00177

4. Dwyer JT, Coates PM, Smith MJ. Dietary supplements: Regulatory challenges and research resources [Internet]. Nutrients. 2018. DOI: http://dx.doi.org/10.3390/nu10010041

5. Vohra S, Cvijovic K, Boon H, Foster BC, Jaeger W, LeGatt $D$, et al. Study of natural health product adverse reactions (SONAR): Active surveillance of adverse events following concurrent natural health product and prescription drug use in community pharmacies. PLoS One [Internet]. 2012; DOI: http://dx.doi.org/10.1371/journal.pone.0045196

6. Mills S, Bone K. Principles and practice of phytotherapy: modern herbal medicine. 2 nd ed. Edinburgh: Churchill Livingstone; 2013. 1051 p.

7. Fasipe O. Recent advances and current trend in the pharmacotherapy of obesity. Arch Med Heal Sci [Internet]. 2018; DOI: http://dx.doi.org/10.4103/amhs.amhs 3018

8. Poulton AS, Hibbert EJ, Champion BL, Nanan RKH. Stimulants for the control of hedonic appetite. Front Pharmacol [Internet]. 2016; DOI: http://dx.doi.org/10.3389/fphar.2016.00105

9. Cheung BMY, Cheung TT, Samaranayake NR. Safety of antiobesity drugs. Ther Adv Drug Saf [Internet]. 2013; DOI: http://dx.doi.org/10.1177/2042098613489721

10. Cohen PA. The FDA and Adulterated Supplements-Dereliction of Duty [Internet]. JAMA network open. 2018.2 DOI: http://dx.doi.org/10.1001/jamanetworkopen.201 $\underline{8.3329}$

11. Vaysse J, Balayssac $\mathrm{S}$, Gilard V, Desoubdzanne D, Malet-Martino M, Martino R. Analysis of adulterated herbal medicines and dietary supplements marketed for weight loss by DOSY 1H-NMR. Food Addit Contam - Part A Chem Anal Control Expo Risk Assess [Internet]. 2010;
DOI:

http://dx.doi.org/10.1080/19440041003705821

12. Galvalisi M, Prieto JP, Martínez M, AbinCarriquiry JA, Scorza C. Caffeine Induces a Stimulant Effect and Increases Dopamine Release in the Nucleus Accumbens Shell Through the Pulmonary Inhalation Route of Administration in Rats. Neurotox Res [Internet]. 2017; DOI: http://dx.doi.org/10.1007/s12640-016-9667-8

13. Yano HM, Santos AP, Bugno A, Auricchio MT. Pesquisa de anorexígenos e benzodiazepínicos em formulações emagrecedoras e avaliação de rotulagem, em análises da Seção de Farmacognosia do Instituto Adolfo Lutz no período de junho de 2004 a março de 2007. Rev Inst Adolfo Lutz. 2008;67(1):78-82.

14. Pringle A, Warren M, Gottwald J, Cowen PJ, Harmer CJ. Cognitive mechanisms of diazepam administration: a healthy volunteer model of emotional processing. Psychopharmacology (Berl) [Internet]. 2016; DOI: http://dx.doi.org/10.1007/s00213-016-4269-y

15. Kripke DF. Mortality Risk of Hypnotics: Strengths and Limits of Evidence. Drug Saf [Internet]. 2016; DOI: http://dx.doi.org/10.1007/s40264-015-0362-0

16. Tucker J, Fischer T, Upjohn L, Mazzera D, Kumar M. Unapproved Pharmaceutical Ingredients Included in Dietary Supplements Associated With US Food and Drug Administration Warnings. JAMA Netw open [Internet]. 2018; DOI: http://dx.doi.org/10.1001/jamanetworkopen.201 $\underline{8.3337}$

17. Pamukcu Gunaydin G, Dogan NO, Levent $S$, Kurtoglu Celik G. Herbal Weight Loss Pill Overdose: Sibutramine Hidden in Pepper Pill. Case Rep Emerg Med. 2015;

18. Rocha T, Amaral JS, Oliveira MBPP. Adulteration of Dietary Supplements by the Illegal Addition of Synthetic Drugs: A Review. Compr Rev Food Sci Food Saf [Internet]. 2016; DOI: http://dx.doi.org/10.1111/1541-4337.12173

19. ANVISA. Federal Law n. 9,782 of January 26th of 1999. Defines the national system of sanitary surveillance ("Sistema Nacional de 
Vigilância Sanitária" - SNVS), and creates the national agency of sanitary surveillance Agencia Nacional de Vigilancia Sanitária - A. 1999.

20. ANVISA. Resolution No 18 of April 30, 1999. Technical Regulation establishing the basic guidelines for analysis and verification of functional and or health alleged in food labeling, in the Annex of this Ordinance. DOU - Official Gazette. 1999.

21. Figueiredo AVA, Recine E, Monteiro R. Food risk regulation: The tensions of the Brazilian health surveillance system. Cienc e Saude Coletiva [Internet]. 2017; DOI: http://dx.doi.org/10.1590/141381232017227.25952015

22. ANVISA. Federal Law n. 8,078 of September 11th of 1990. Provides for consumer protection and makes other provisions. 1990.

23. ANVISA. Brazilian Pharmacopoeia. 5th ed. Brasilia; 2010.

24. Ciura K, Dziomba S, Nowakowska J, Markuszewski MJ. Thin layer chromatography in drug discovery process [Internet]. Vol. 1520, Journal of Chromatography A. Elsevier B.V.; 2017. p. 9-22.

DOI: http://dx.doi.org/10.1016/j.chroma.2017.09.015

25. Coskun O. Separation Tecniques: CHROMATOGRAPHY. North Clin Istanbul [Internet]. 2016; DOI: http://dx.doi.org/10.14744/nci.2016.32757

26. ANVISA. RDC n. 26, of May 13th, 2014. Provides for phytotherapic drugs registration and the registry and notification of traditional phytotherapic products. 2014.

27. ANVISA. Normative Instruction n. 4, of June 18th, 2014. Determines the publication of the Guide for Orientation for Phytotherapic Drug Registry and the registry and notification of traditional phytotherapic products. 2014.

28. ANVISA. Methodological Guidelines: Elaboration of Clinical Guidelines. 2016.

29. ANVISA. RDC n. 9 of February 20th of 2015. Provides for the Regulation for realization of clinical assays with medicines in Brazil. 2015.
30. ANVISA. Decree n. 85,878 of April 21st of 1981. Stablish norms for execution of Law $n$. 3,820 of November 11th of 1960, about the exercise of pharmacist profession, and deals with other providences. Brasília, DF, 1981. 1981.

31. Kokotkiewicz A, Migas P, Stefanowicz J, Luczkiewicz $M$, Krauze-Baranowska $M$. Densitometric TLC analysis for the control of tropane and steroidal alkaloids in Lycium barbarum. Food Chem [Internet]. 2017 Apr 15;221:535-40.

DOI: http://dx.doi.org/10.1016/j.foodchem.2016.11.1 $\underline{42}$

32. de Bona AP, Batitucci MCP, Andrade MA, Riva JAR, Perdigão TL. Estudo fitoquímico e análise mutagênica das folhas e inflorescências de Erythrina mulungu (Mart. ex Benth.) através do Teste de Micronúcleo em roedores. Rev Bras Plantas Med [Internet]. 2012;14(2):344-51. DOI: http://dx.doi.org/10.1590/S151605722012000200014

33. Amorim J, Borges $M$ de $C$, Fabro AT, Contini SHT, Valdevite M, Pereira AMS, et al. The ethanolic extract from Erythrina mulungu Benth. flowers attenuates allergic airway inflammation and hyperresponsiveness in a murine model of asthma. J Ethnopharmacol [Internet]. 2019 Oct $5 ; 242$.

DOI:

\section{http://dx.doi.org/10.1016/j.jep.2018.08.009}

34. Cao Y, He Y, Wei C, Li J, Qu L, Zhang H, et al. Aquaporins alteration profiles revealed different actions of senna, sennosides, and sennoside $a$ in diarrhea-rats. Int J Mol Sci [Internet]. 2018 Oct 17;19(10). DOI: http://dx.doi.org/10.3390/ijms19103210

35. Pastoriza S, Mesías M, Cabrera C, RufiánHenares JA. Healthy properties of green and white teas: An update [Internet]. Vol. 8, Food and Function. Royal Society of Chemistry; 2017. p. 2650-62.

DOI:

http://dx.doi.org/.1039/c7fo00611j

36. Prasanth MI, Sivamaruthi BS, Chaiyasut C, Tencomnao T. A review of the role of green tea (camellia sinensis) in antiphotoaging, stress resistance, neuroprotection, and autophagy [Internet]. Vol. 11, Nutrients. MDPI AG; 2019. DOI: http://dx.doi.org/10.3390/nu11020474 
37. Araldi RP, Rechiutti BM, Mendes TB, Ito ET, Souza EB. Mutagenic potential of Cordia ecalyculata alone and in association with Spirulina maxima for their evaluation as candidate anti-obesity drugs. Genet Mol Res [Internet]. 2014 Jul 7;13(3):5207-20. DOI: http://dx.doi.org/10.4238/2014.July.7.14

38. Sant'ana Verly B, Augusta Grigoli Dominato A. Identificação de adulterantes benzodiazepínicos em medicamentos fitoterápicos. Colloq Vitae [Internet]. 2014;06(03):113. DOI: http://dx.doi.org/10.5747/cv.2014.v06.n3.v113

39. Azeredo FS de. Validação de técnica analítica em cromatografia em camada delgada comparativa para identificação de fármacos anorexígenos sintéticos em produtos fitoterápicos. Rev Eletrônica Farmácia [Internet]. 2007;

DOI:

http://dx.doi.org/10.5216/ref.v1i2.1751 